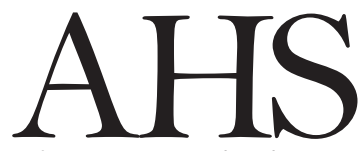

Advances in Horticultural Science

\title{
Improving 'Piyarom' date palm fruit quality with fruit thinning and bunch covering treatments
}

\author{
B. Madani ${ }^{1(*)}$, A.M. Dastjerdy ${ }^{2}{ }^{(*)}$, A. Shahriyari ${ }^{1}$ \\ 1 Horticultural Crops Research Department, Natural Resources Research \\ and Education Center of Hormozgan, AREEO, Bandar Abbas, Iran. \\ 2 Department of Horticultural Science, Faculty of Agriculture and Natural \\ Resources, University of Hormozgan, Bandar Abbas, Iran.
}

Key words: Khalal, Kimri, Phoenix dactylifera L., quality, Tamar.

Abstract: 'Piyarom' dates are one of the most important commercial date cultivars grown in Iran but fruit quality and postharvest losses can be a problem. Thinning and the use of bunch covers were examined to improve the date fruit quality. Three different levels of fruit thinning were applied (without thinning, removal of one third of total strands from terminal tips during pollination and removal of one third of terminal tips of central strands in early kimri). In addition, the effects of bunch covers were assessed with the use of polyethylene bunch covers that were applied in the early stages of Khalal. The results showed that bunch covering reduced the lightness of the fruit but increased bunch weight, fruit length, total antioxidant activity and total phenolic compounds compared to the control. Thinning during pollination increased the weight of the fruit compared to the control. The thinning during Kimri stage increased the percentage of Tamar and ascorbic acid content. These results show that the use of covers play a positive role in increasing quality and bunch weight and thinning at both pollination and Kimri ripening stage is recommended to produce high quality 'Piyarom' dates.

(C) 2021 Madani B., Dastjerdy A.M., Shahriyari A. This is an open access, peer reviewed article published by Firenze University Press (http://www.fupress.net/index.php/ahs/) and distributed under the terms of the Creative Commons Attribution License, which permits unrestricted use, distribution, and reproduction in any medium, provided the original author and source are credited.

Data Availability Statement:

All relevant data are within the paper and its Supporting Information files.

Competing Interests:

The authors declare no competing interests.

Received for publication 16 April 2020

Accepted for publication 24 December 2020

\section{Introduction}

Date palms (Phoenix dactylifera L.) are an ancient horticultural crop cultivated for its sweet fruit which are also rich in nutrients, antioxidants and phenolic compounds (Hussain et al., 2016). Iran is one of the largest producing countries of dates growing 171,647 hectares of date palms with an annual production of 1,204,158 tons (FAO, 2018).

Date fruit has five stages of growth and ripening; (1) Hababouk (cell division and elongation), (2) Kimri (firm full colored), (3) Khalal (physiologically mature with a hard and crisp texture and a moisture content between 50-85\%), (4) Rutab (partially browned, reduced moisture content $30-45 \%$, fibres softened, perishable), and (5) Tamar (fruit colour from amber to dark brown with a moisture content further reduced - below $25 \%$ down to $10 \%$ and less, and the texture is soft pliable to firm to hard) 
(Awad and Al-Qurashi, 2012). Date palm (Phoenix dactylifera L.) cv. Piyarom is one of the most important commercial semi-dry dates in Iran which is consumed at tamar ripening stage and fruit reaches full maturity. It is widely grown in Hormozgan province of Iran with increasing export production. In commercial production, larger fruit with higher quality are more marketable and therefore fruit thinning is one of the main agronomic methods to improve fruit size and quality. Fruit thinning is widely used in horticultural production which increases fruit quality, reduces bi-annual bearing and ensures a physiological balance between vegetative and reproductive parts due to reduced competition for water and food absorption (Slatnar et al., 2020). There are different times and methods for date palm thinning. For example, thinning $1 / 3$ of the bunch at pollination period or $1 / 3$ terminal tips of central strands in early kimri stage of fruit development, as has been described by El-Badawy et al. (2018) and Moustafa et al. (2019). However some date palm cultivars can react contrarily to the different treatments of thinning for example, Awad and Al-Qurashi (2015) reported that thinning 5-10 cm bunch four weeks after pollination in 'Barhee' date did not affect the qualitative characters of fruit. However, Ahmed et al. (2019) showed that thinning $1 / 3$ terminal tips of central strands in early Kimri stage of fruit development of 'Zaghlool' decreased titrable acidity and increased soluble solid content. However there has been no research on the effects of different thinning options on the quality of 'Piyarom' date where most farmers in southern Iran currently use bunch thinning only at pollination period.

Pre-harvest covering of fruit is practiced in many crops and its usage is increasing in many countries to improve fruit quality. However, the effects of fruit covering on final fruit quality is variable and reflect differences in the covering type, fruit age at covering and cultivar response (Sharma et al., 2014). For example Kassem et al. (2010) stated that 'Zaghlool' dates covering with dark polyethylene at kimri stage did not affect total acidity (TA) and total soluble solid content (TSS). However, Awad and Al-Qurashi (2012) concluded that bunch craft bagging after pollination increased bunch weight, TA and TSS, ascorbic acid and decreased total phenols and Rutab percentage of 'Barhee' date. Harhash and Al-Obeed (2010) showed that bunch bagging increased fruit and bunch weight and quality of 'Succary' and 'Khalas' dates. Harhash et al. (2020) further showed that bunch weight was greatly increased by covering bunches with white paper and white and brown cloth as compared to control. Fruit weight was increased remarkably by using white or kraft paper and white or brown cloth in covering bunches of 'Barhee' date palm while TSS was increased in the fruit which were produced from bunch covering with white or kraft paper and white or brown cloth over control.

Due to its high consumer appeal, 'Piyarom' date is a promising cultivar for export but a more consistent high fruit quality is required. Therefore, this study assessed the effects of both date fruit thinning and the use of bunch covers on the bunch weight and quality of 'Piyarom' dates over two seasons.

\section{Materials and Methods}

\section{Experimental procedure}

Fruits selected for this trial were from 'Piyarom' date palms of the same age (18 years old) and size which were grown on sandy loam soil and drip irrigated at the Hajiabad Agricultural Research Station in Hormozgan province in Iran for two years during 2018-2019. All regular cultural practices were conducted according to the normal commercial schedules. Pollination was conducted using a local 'Green' male cultivar to manually pollinate the female flowers in April each year with a total of eight 8 bunches were left on each experimental tree.

This trial was a factorial trial with fruit thinning and bunch covers as the two factors. Within the fruit thinning treatment, three levels of thinning were examined; (1) removal of one third of the end of total strands from terminal tips of bunch at the time of pollination, (2) removal of one third of terminal tips of central strands in early Kimri (performed in June), and (3) untreated flowers (control). The second factor of experiment was bunch covering at two levels (uncovered bunches and bunch covering with polyethylene mesh which consisted on a $100 \mathrm{~cm}$ long and $80 \mathrm{~cm}$ wide bag with mesh holes (diameter of each hole is about $2 \mathrm{~mm}$ ) which were applied in early stage of Khalal. The thinning treatments and bunch coverings were performed on four bunches in each palm tree, and fruit sampling of these bunches was performed at harvest. In November on each tree, all bunches were harvested and bunch weight per palm was recorded. The Tamar percentage was also calculated. Fruit samples were collected at the Tamar stage for physicochemical characteristics measure- 
ments.

\section{Physico-chemical characters}

At harvest time (Tamar stage), 100 fruit subsamples from each replicate were sampled from palm trees and the factors related to the colour of the fruit measured by Minolta (CR-300, Minolta Corp, Osaka, Japan) colorimeter and expressed as $L^{*}, C^{*}$ and $h^{\circ}$.

Fruit weight, length and diameter of each fruit and seed were measured on 25 fruit per replicate. Fruit and seed length and diameter were measured by a digital caliper and the weight of the fruit and seed were measured by a digital scale. Fruit total soluble solid content (TSS), ascorbic acid, moisture content, total phenolic compounds and total antioxidant activity were measured on a composite sample of 20 fruit per replicate. TSS was measured as Brix \% with a digital refractometer (DBR95, Taiwan). The spectrophotometric method was used for measuring ascorbic acid content (Etemadipoor et al., 2019). Ten $\mathrm{ml}$ of distilled water used for homogenizing one gram of fruit tissue. Then, the solution filtered and $0.1 \mathrm{ml}$ of it was added to $1 \%$ metaphosphoric acid. Then, solution combined with $9 \mathrm{ml}$ of 2, 6-dichloro indophenol $(0.0025 \%)$. After that, the mixture absorbance was evaluated by spectrophotometer (Cecil, CE2501, England) at $517 \mathrm{~nm}$. The results were reported accordingly ( $\mathrm{mg} / 100 \mathrm{~g}$ fresh fruit tissue). For moisture content $20 \mathrm{~g}$ of fruit sample from each replicate was cut into small pieces by a sterilized knife. Then, the fresh weight of each sample was measured. Then, dried to a constant weight in oven at $70^{\circ} \mathrm{C}$. Dry weight was measured and fruit moisture expressed as percentage (Marzouk and Kassem, 2011).

Total antioxidant activity (TAA), total phenolic content (TPC)

Measuring TAA involved adding $1 \mathrm{ml} \mathrm{2,2-}$ Diphenyl-1-picryl-hydrazyl (DPPH) $(0.1 \mathrm{mM})$ to $0.1 \mathrm{ml}$ methanolic extract. This solution was subsequently mixed with $1 \mathrm{ml}$ of Tris- $\mathrm{HCl}(\mathrm{pH} 7.5)$. The absorption value of each sample was determined at $517 \mathrm{~nm}$ wavelength via spectrophotometer (Cecil, CE2501, England) (Etemadipoor et al., 2020). The antioxidant activity was determined as follows:

Antioxidant activity $(\%)=[1-($ Abs sample /Abs control $) \times 100]$

The Folin-Ciocalteu reagent was used for measuring TPC (Ehteshami et al., 2019). Briefly, fruit tissue $(0.5 \mathrm{~g})$ was squashed and mixed into methanol $(3 \mathrm{ml}$, $85 \%)$. The resultant solution was centrifuged at
$12,000 \times g$ at $4^{\circ} \mathrm{C}$ for $20 \mathrm{~min}$. The extract was considered as supernatant. Then, $300 \mu$ l of extract was combined with sodium carbonate $(1.2 \mathrm{ml}, 7 \%)$. This mixture was stored at ambient temperature for 5 min. After that Folin-Ciocalteu $(10 \%, 1.5 \mathrm{ml})$ was added. The absorbance was determined at $760 \mathrm{~nm}$ and TPC was presented as $\mathrm{mg}$ GAE $100 \mathrm{~g}^{-1} \mathrm{FW}$.

\section{Statistical analysis of data}

The experimental was as factorial in a randomized complete block design with three replicates (block) and each replicate consisted of two palm tree. Two factors included bunch thinning and bunch covering. Bunch thinning consisted of 3 levels and bunch covering consisted of 2 levels. The treatment unit consisted of four bunches on each of the two tree treatment blocks. Data were analyzed by Statistical Analysis System version 9.1 (SAS Institute Inc., Cary, NC, USA). The means were compared using LSD at a significance level of $p=0.05$.

\section{Results and Discussion}

\section{Bunch weight and Tamar percentage}

The results of this experiment showed that the coverage did not have a significant effect on the percentage of Tamar, but date palm fruit thinning in the Kimri and pollination stages significantly increased Tamar percentage of both years (Table 1). The Tamar percentage was approximately $94.25-113.75 \%$ higher than the control group and occurred as a result of thinning in the Kimri stage during both years of experiment. Also, the bunch weight was significantly higher in the control as compared to bunch weights that occurred after date palm fruit thinning at the pollination and Kimri stages, for both years (Table 1). In this research, the Tamar percentage was not affected by covering. In the available literature, there are inconsistent results on the use of covering for fruit ripening. For example, Awad and Al-Qurashi (2012) stated that bunch bagging of 'Barhee' date can eventually reduce the percentage of Rutab in comparison with the control. However, Kassem et al. (2011) stated that spathe-bagging increased fruit ripening in 'Zaghlool' date, as compared to the control. Tamar is the last stage of 'Piyarom' date fruit maturity. However, date fruit do not ripen evenly, and even in a bunch Rutab and Khalal can be observed at harvest. This causes economic loss of fruit. Therefore, increasing Tamar percentage in the bunch can rise the commercial value of product. The 
Table 1 - Main effects of bunch date palm fruit thinning and covering on bunch weight and Tamar percentage of 'Piyarom' date

\begin{tabular}{|c|c|c|}
\hline Treatment & $\begin{array}{l}\text { Bunch } \\
\text { weight } \\
\text { (kg) }\end{array}$ & $\begin{array}{c}\text { Tamar } \\
(\%)\end{array}$ \\
\hline \multicolumn{3}{|l|}{2018} \\
\hline \multicolumn{3}{|l|}{ Thinning } \\
\hline Control & $15.49 a^{2}$ & $29.16 \mathrm{c}$ \\
\hline $\begin{array}{l}\text { Removal of one third of total strands from } \\
\text { terminal tips during pollination }\end{array}$ & $13.44 \mathrm{~b}$ & $49.33 \mathrm{~b}$ \\
\hline $\begin{array}{l}\text { Removal of one third of terminal tips of } \\
\text { central strands in early Kimri }\end{array}$ & $11.37 \mathrm{c}$ & $62.33 \mathrm{a}$ \\
\hline LSD & 4.89 & 3.82 \\
\hline \multicolumn{3}{|l|}{ Bunch covering } \\
\hline Control & $13.09 \mathrm{~b}$ & $47.66 \mathrm{a}$ \\
\hline Bunch covering & 13.77 a & $46.22 \mathrm{a}$ \\
\hline LSD & 3.99 & 3.12 \\
\hline Thinning $x$ bunch covering & NS ${ }^{y}$ & NS \\
\hline \multicolumn{3}{|l|}{2019} \\
\hline \multicolumn{3}{|l|}{ Thinning } \\
\hline Control & $15.51 \mathrm{a}$ & $32.00 \mathrm{c}$ \\
\hline $\begin{array}{l}\text { Removal of one third of total strands from } \\
\text { terminal tips during pollination }\end{array}$ & $14.05 \mathrm{~b}$ & $45.66 \mathrm{~b}$ \\
\hline $\begin{array}{l}\text { Removal of one third of terminal tips of } \\
\text { central strands in early Kimri }\end{array}$ & $11.00 \mathrm{c}$ & $62.16 \mathrm{a}$ \\
\hline LSD & 3.23 & 5.10 \\
\hline \multicolumn{3}{|l|}{ Bunch covering } \\
\hline Control & $13.29 \mathrm{~b}$ & $46.33 \mathrm{a}$ \\
\hline Bunch covering & $13.75 \mathrm{a}$ & $46.88 \mathrm{a}$ \\
\hline LSD & 2.64 & 4.16 \\
\hline Thinning $\mathrm{x}$ bunch covering & NS & NS \\
\hline $\begin{array}{l}\text { Means within each column for each treat } \\
\text { same letter are not significantly different } \\
\text { y } \mathrm{NS}=\text { non significant. }\end{array}$ & $\begin{array}{l}\text { t followe } \\
=0.05 \text {. }\end{array}$ & $\mathrm{d}$ by the \\
\hline
\end{tabular}

increase in the percentage of Tamar, as a result of the thinning treatment, can be due to a lowered level of competition between fruit for the absorption of water and nutrients, thereby accelerating fruit maturity and increasing the percentage of Tamar (Radwan, 2017). The results of this study on increasing bunch weight of the control, as compared to the date palm fruit thinning treatment, are consistent with previous results (Moustafa et al., 2019) on the Khadravi cultivar. However, the primary goal is to determine an optimum method of date palm fruit thinning so as to improve fruit quality, obtain a reasonable bunch weight and thus enhance marketability.

TAA, TPC

The antioxidant properties of date fruit differ depending on the amount of phenolic compounds in the fruit (Hussain et al., 2016). Phenolic compounds account for most of the antioxidant properties of dates. They exhibit a range of biological effects such as the prevention of nucleic acid damage. There has been growing interest in the topic of antioxidants, regarding the ability of antioxidants to scavenge free radicals associated with various diseases (Aleid, 2014). Thus, dates can be used as antioxidative functional food ingredients (Aleid, 2014). Fruit of different date palm cultivars have different total phenolic contents and antioxidant activities (Al-Turki et al., 2010).

In the current study, comparison of the main effects of date palm fruit thinning on total antioxidant activity (TAA) showed that date palm fruit thinning during the Kimri phase increased the TAA as compared to the control (Table 2). Also, date palm fruit thinning during the Kimri phase increased the TPC as compared to the control for both years. Moreover, bunch covering increased TAA and TPC

Table 2 - Effect of fresh organic amendments on nematode population, gall number and galling index

\begin{tabular}{|c|c|c|}
\hline Treatments & TAA (\%) & $\begin{array}{c}\text { TPC } \\
\text { (mg GAE } \\
100 \mathrm{~g} \mathrm{fw})\end{array}$ \\
\hline \multicolumn{3}{|l|}{2018} \\
\hline \multicolumn{3}{|l|}{ Thinning } \\
\hline Control & $49.66 c^{2}$ & $130.16 \mathrm{~b}$ \\
\hline $\begin{array}{l}\text { Removal of one third of total strands } \\
\text { from terminal tips during pollination }\end{array}$ & $67.26 \mathrm{~b}$ & $135.45 \mathrm{ab}$ \\
\hline $\begin{array}{l}\text { Removal of one third of terminal tips } \\
\text { of central strands in early Kimri }\end{array}$ & 70.43 a & $138.21 \mathrm{a}$ \\
\hline LSD & 2.89 & 5.73 \\
\hline \multicolumn{3}{|l|}{ Bunch covering } \\
\hline Control & $58.73 \mathrm{~b}$ & $131.23 \mathrm{~b}$ \\
\hline Bunch covering & 66.17 a & 137.98 a \\
\hline LSD & 2.36 & 4.68 \\
\hline Thinning $x$ bunch covering & $\mathrm{NS}^{\mathrm{y}}$ & NS \\
\hline \multicolumn{3}{|l|}{2019} \\
\hline \multicolumn{3}{|l|}{ Thinning } \\
\hline Control & $48.18 \mathrm{c}$ & $126.51 \mathrm{~b}$ \\
\hline $\begin{array}{l}\text { Removal of one third of total strands } \\
\text { from terminal tips during pollination }\end{array}$ & $67.83 \mathrm{~b}$ & 141.16 a \\
\hline $\begin{array}{l}\text { Removal of one third of terminal tips } \\
\text { of central strands in early Kimri }\end{array}$ & $71.10 \mathrm{a}$ & 140.06 a \\
\hline LSD & 2.21 & 4.15 \\
\hline \multicolumn{3}{|l|}{ Bunch covering } \\
\hline Control & $57.31 \mathrm{~b}$ & $134.28 \mathrm{~b}$ \\
\hline Bunch covering & $67.43 \mathrm{a}$ & $138.21 \mathrm{a}$ \\
\hline LSD & 1.80 & 3.39 \\
\hline Thinning $\mathrm{x}$ bunch covering & NS & NS \\
\hline
\end{tabular}

z Means within each column for each treatment followed by the same letter are not significantly different at $\mathrm{P}=0.05$.

y $\mathrm{NS}=$ non significant. 
compared to the control for both years (Table 2). Little research exists on the effects of bunch thinning and covering on TAA and TPC of date. Hussain et al. (2016) stated that thinning treatments of 'Hillawi' and 'Khadrawi' increased TPC in comparison with the control, probably because of a greater light exposure to the fruit in response to less fruit density in each bunch. Indeed, light plays an important role in processes that are responsible for the accumulation of phenolic compounds. On the other hand, in fruit of the control group, there were lower amounts of light and air circulation available to the fruit, thereby affecting the rate of photosynthetic carbon assimilation rate and TPC (Hussain et al., 2016). The contradictory effects of covering on phenolic-compound might be due to differences in the covering material, exact time and period of covering, cultivars and climatic conditions (Sharma and Sanikommu, 2018). Chen et al. (2012) stated that fruit bagging reduced the concentration of phenolic compounds in 'Golden Delicious' apple, whereas Griñán et al. (2019) report- ed that pomegranate fruit bagging increased the antioxidant content.

\section{Physiochemical characteristics}

Comparison of main effects of coverage on color lightness, chroma and hue showed that coverage significantly reduced the lightness and chroma, while at the same time increased the hue in comparison with the control for both years (Table 3). Also, the comparison of main effects of thinning on lightness, chroma and hue showed that thinning in pollination and the early Kimri stage significantly reduced the lightness and chroma, compared to the control. In addition, this treatment increased the hue in fruit, compared to the control for both years (Table 3 ). The colour of date fruit is one of the most important factors that can largely influence customers and can determine prices. So far, the available literature does not include measurements of lightness, chroma and hue when bunch covering and thinning are used as treatments for date palm. The positive correlation

Table 3 - Main effects of bunch date palm fruit thinning and covering on colour, TSS, ascorbic acid and moisture of 'Piyarom' date

\begin{tabular}{|c|c|c|c|c|c|c|}
\hline Treatment & $\begin{array}{c}\mathrm{L} \\
(*)\end{array}$ & $\begin{array}{c}\mathrm{C} \\
\left({ }^{*}\right)\end{array}$ & $\begin{array}{l}\mathrm{H} \\
(\circ)\end{array}$ & $\begin{array}{c}\text { TSS Brix } \\
(\%)\end{array}$ & $\begin{array}{c}\text { Ascorbic } \\
\text { acid } \\
\left(\mathrm{mg} 100 \mathrm{~g}^{-1}\right)\end{array}$ & $\begin{array}{c}\text { Moisture } \\
\text { (\%) }\end{array}$ \\
\hline \multicolumn{7}{|l|}{2018} \\
\hline \multicolumn{7}{|l|}{ Thinning } \\
\hline Control & $30.31 a^{z}$ & 11.99 a & $40.83 \mathrm{c}$ & $61.11 b$ & $6.06 c$ & $12.13 \mathrm{a}$ \\
\hline Removal of one third of total strands from terminal tips during pollination & $25.66 \mathrm{~b}$ & $9.45 b$ & $46.98 \mathrm{~b}$ & $63.11 \mathrm{~b}$ & $11.25 \mathrm{~b}$ & $11.25 \mathrm{a}$ \\
\hline Removal of one third of terminal tips of central strands in early Kimri & $22.58 \mathrm{c}$ & $7.12 \mathrm{c}$ & $51.80 \mathrm{a}$ & $66.05 \mathrm{a}$ & 13.46 a & 11.86 a \\
\hline LSD & 2.19 & 1.49 & 2.60 & 2.41 & 1.11 & 1.19 \\
\hline \multicolumn{7}{|l|}{ Bunch covering } \\
\hline Control & $27.50 \mathrm{a}$ & $10.19 \mathrm{a}$ & $45.21 \mathrm{~b}$ & $63.01 \mathrm{a}$ & $10.68 \mathrm{a}$ & $11.95 \mathrm{a}$ \\
\hline Bunch covering & $24.84 b$ & $8.85 b$ & $47.86 \mathrm{a}$ & $63.84 \mathrm{a}$ & 9.83 a & $11.54 \mathrm{a}$ \\
\hline LSD & 1.79 & 1.22 & 2.13 & 1.97 & 0.90 & 0.97 \\
\hline Thinning $x$ bunch covering & $\mathrm{NS}^{\mathrm{r}}$ & NS & NS & NS & NS & NS \\
\hline \multicolumn{7}{|l|}{2019} \\
\hline \multicolumn{7}{|l|}{ Thinning } \\
\hline Control & $28.75 \mathrm{a}$ & $11.14 \mathrm{a}$ & $44.71 \mathrm{c}$ & $62.01 \mathrm{c}$ & $6.81 \mathrm{c}$ & $10.76 \mathrm{a}$ \\
\hline Removal of one third of total strands from terminal tips during pollination & $24.06 \mathrm{~b}$ & $8.05 \mathrm{~b}$ & $50.30 \mathrm{~b}$ & $64.88 \mathrm{~b}$ & $12.13 \mathrm{~b}$ & $11.60 \mathrm{a}$ \\
\hline Removal of one third of terminal tips of central strands in early Kimri & $21.90 \mathrm{~b}$ & $6.36 \mathrm{c}$ & $55.73 \mathrm{a}$ & $67.45 \mathrm{a}$ & $13.66 \mathrm{a}$ & $10.41 \mathrm{a}$ \\
\hline LSD & 2.41 & 1.25 & 3.34 & 2.26 & 1.28 & 1.61 \\
\hline \multicolumn{7}{|l|}{ Bunch covering } \\
\hline Control & $25.90 \mathrm{a}$ & 9.17 a & $47.87 \mathrm{~b}$ & 64.96 a & $11.34 \mathrm{a}$ & $11.09 \mathrm{a}$ \\
\hline Bunch covering & $23.91 b$ & $7.86 \mathrm{~b}$ & $52.62 \mathrm{a}$ & $64.60 \mathrm{a}$ & $10.40 \mathrm{a}$ & $10.75 \mathrm{a}$ \\
\hline LSD & 1.96 & 1.02 & 2.72 & 1.85 & 1.04 & 1.31 \\
\hline Thinning $\mathrm{x}$ bunch covering & NS & NS & NS & NS & NS & NS \\
\hline
\end{tabular}

z Means within each column for each treatment followed by the same letter are not significantly different at $\mathrm{P}=0.05$.

y NS= non significant. 
between TAA and hue has been shown in table 4 . Based on our results, bunch covering increased TAA which can be effective in improving the colour of the fruit (Siddiq et al., 2013). The mechanism involves the formation of dark pigments on fruit, thereby reducing the brightness of the fruit and increasing hue in fruit (Siddiq et al., 2013). On similar accounts, covering has reportedly improved the colour of apple (Sharma and Pal, 2012). A more pronounced fruit colouring is one of the most important goals of thinning. The increase in fruit colour, as a result of the date palm fruit thinning treatment, is due to the absorption of more nutrients in the remaining fruit and also due to the release of more sugars that lead to antioxidant compounds and dark pigments in fruit (Hussain et al., 2016). These results are comparable with previous results reported by Ahmed et al. (2019) where date palm fruit thinning increased the colour index in 'Zaghlool' date fruit. The results of statistical compound analysis showed that bunch covering did not affect significantly on soluble solid content (Table 3). Comparison of mean values of the main effects of thinning on TSS showed that thinning in the early Kimri caused a significant increase in TSS compared to thinning at the pollination stage and in the control group (Table 3 ). With the softening of the fruit, astringency is lost and TSS increases, thereby sweetening the fruit (Serrano et al., 2001). The increase in TSS due to thinning usually occurs because of the fact that fruit use more leaf area for the production of photosynthetic materials, soluble carbohydrates and soluble solids as the fruit ripens (Moustafa et al., 2019). The main effects of bunch covering on ascorbic acid content showed that bunch covering did not affect this variable compared to the control. Moreover, comparison of the mean values of the main effects of date palm fruit thinning on ascorbic acid content showed that date palm fruit thinning in the early Kimri caused a significant increase in ascorbic acid compared to the control and also compared to thinning at the pollination stage (Table 3 ). Moreover, Ahmed et al. (2019) reported that date palm fruit thinning increased ascorbic acid in "Zaghlool" dates. Also, Awad and Al-Qurashi (2012) reported that bagging 'Barhee' dates increased ascorbic acid content. However, the mechanism by which bunch covering affects ascorbic acid is not clear. The main effects of bunch date palm fruit thinning and covering on the percentage of fruit moisture were not significant (Table 3). The percentage of fruit moisture is usually affected by many environmental factors and tree management. In some cultivars, thinning of dates reduces the percentage of moisture in the 'Saidy' date palms fruit (Samouni et al., 2016). However Moustafa et al. (2019) showed that date palm fruit thinning does not affect the moisture content of 'Khadrawi' date fruit.

The results of statistical compound analysis showed significant effects of bunch date palm fruit thinning on fruit length, fruit weight and seed length. Comparison of mean values on the main effects of covering bunches revealed that fruit length increased as compared to the control for both years (Table 5). Mean comparison of the main effects showed that date palm fruit thinning caused a significant increase in the length and weight of fruit in comparison with the control for both years. Also, date palm fruit thinning at the time of pollination significantly increased the diameter of fruit and the length of the seeds compared to the control and thinning in the early Kimri stage for both years. Thinning did not affect the weight and diameter of the seeds for both years (Table 5). The effects of coverage on different fruit have been investigated. However, there are contradictory reports on the effects of covering on fruit size. For example, in mango, covering increased the size of the fruit (Chonhenchob et al., 2011). In another study, bagging reduced fruit size in bananas (Hasan et al., 2001). Fruit weight and size usually affect the marketing of dates. Larger sizes have better marketability (Al-Qurashi and Awad, 2011). Thinning can be an important treatment in the orchard which improves the quantitative and qualitative properties of fruit for export. In dates, date palm fruit thinning can be performed until the middle of the Kimri phase. Growth occurs during the cell division and enlargement stages. Cell division occurs after fertilization and continues until the end of the

Table 4 - Pearson correlation between TAA, lightness, chroma and hue

\begin{tabular}{lcccc}
\hline Correlation & TAA & Lightness & Chroma & hue \\
\hline TAA & 1 & $-0.88^{* *}$ & $-0.84^{* *}$ & $0.82^{* *}$ \\
\hline
\end{tabular}

**= Correlation is significant at the 0.01 level. 
Kimri phase. Then, cellular growth ensues. A proper distribution of nutrients during cell division and enlargement increases the size of the fruit and causes better marketability. In the process of fruit growth and development, there is competition for water and nutrients. Thinning reduces competition between fruit for their absorption of water and nutrients, while providing adequate conditions for growth. This reduces the number of fruit and increases the length of the fruit. These results agree with the results of Ahmed et al. (2019) that thinning in 'Zaghlool' dates at an early stage of fruit development can have a greater effect on fruit size due to a more comprehensive allocation of water and nutrients.

\section{Conclusions}

The results of this study showed that covering the date bunch reduced the brightness of the fruit, but increased the bunch weight, fruit length, total antioxi- dant activity and total phenolic compounds. Thinning at the pollination stage increased the weight of the fruit compared to the control. Thinning at the Kimri stage increased the percentage of Tamar, ascorbic acid content, and total antioxidant activity. We conclude that bunch covering at the pre-harvest stage is a simple, grower-friendly method. It is safe to use and has several beneficial effects on the physiochemical traits of fruit. This approach can be an integral part of fruit production in orchards. Moreover, fruit thinning and covering increased total antioxidant activity and total phenolic compounds of fruit which are important quality factors. Also, thinning is recommended for 'Piyarom' dates at both pollination and Kimri stages.

\section{Acknowledgements}

The authors would like to thank Prof. John B. Golding for critical review and revising the manuscript.

Table 5 - Main effects of bunch date palm fruit thinning and covering on fruit and seed length, diameter and weight of 'Piyarom' date

\begin{tabular}{|c|c|c|c|c|c|c|}
\hline Treatments & $\begin{array}{l}\text { Fruits } \\
\text { length } \\
(\mathrm{cm})\end{array}$ & $\begin{array}{c}\text { Fruits } \\
\text { diameter } \\
(\mathrm{cm})\end{array}$ & $\begin{array}{c}\text { Fruits } \\
\text { weight } \\
\text { (g) }\end{array}$ & $\begin{array}{c}\text { Seed } \\
\text { length } \\
(\mathrm{cm})\end{array}$ & $\begin{array}{c}\text { Seed } \\
\text { diameter } \\
(\mathrm{cm})\end{array}$ & $\begin{array}{l}\text { Seed } \\
\text { weight } \\
\text { (g) }\end{array}$ \\
\hline \multicolumn{7}{|l|}{2018} \\
\hline \multicolumn{7}{|l|}{ Thinning } \\
\hline Control & $3.42 c^{2}$ & $1.78 \mathrm{~b}$ & $6.75 \mathrm{c}$ & $2.30 \mathrm{~b}$ & $1.06 \mathrm{a}$ & $0.99 \mathrm{a}$ \\
\hline Removal of one third of total strands from terminal tips & $4.95 \mathrm{a}$ & $2.76 \mathrm{a}$ & $10.46 \mathrm{a}$ & $3.10 \mathrm{a}$ & $1.08 \mathrm{a}$ & $1.05 \mathrm{a}$ \\
\hline Removal of one third of terminal tips of central strands in & $4.30 \mathrm{~b}$ & $1.95 \mathrm{~b}$ & $8.77 \mathrm{~b}$ & $2.10 \mathrm{~b}$ & $1.00 \mathrm{a}$ & $1.11 \mathrm{a}$ \\
\hline LSD & 0.42 & 0.52 & 1.45 & 0.32 & 0.21 & 0.18 \\
\hline \multicolumn{7}{|l|}{ Bunch covering } \\
\hline Control & $3.97 \mathrm{~b}$ & $2.33 \mathrm{a}$ & $8.34 \mathrm{a}$ & $2.50 \mathrm{a}$ & $1.11 \mathrm{a}$ & $1.06 \mathrm{a}$ \\
\hline Bunch covering & $4.48 \mathrm{a}$ & $2.00 \mathrm{a}$ & $8.98 \mathrm{a}$ & $2.50 \mathrm{a}$ & $0.98 \mathrm{a}$ & $1.04 \mathrm{a}$ \\
\hline LSD & 0.34 & 0.42 & 1.18 & 0.26 & 0.17 & 0.15 \\
\hline Thinning $x$ bunch covering & $\mathrm{NS}^{\mathrm{y}}$ & NS & NS & NS & NS & NS \\
\hline \multicolumn{7}{|l|}{2019} \\
\hline \multicolumn{7}{|l|}{ Thinning } \\
\hline Control & $3.75 \mathrm{~b}$ & $1.96 \mathrm{~b}$ & $7.08 \mathrm{c}$ & $2.23 \mathrm{~b}$ & $0.75 \mathrm{a}$ & $0.98 \mathrm{a}$ \\
\hline Removal of one third of total strands from terminal tips & $4.75 \mathrm{a}$ & $3.31 \mathrm{a}$ & $11.50 \mathrm{a}$ & $3.25 \mathrm{a}$ & $0.81 \mathrm{a}$ & $0.99 \mathrm{a}$ \\
\hline Removal of one third of terminal tips of central strands in & $4.66 \mathrm{a}$ & $2.26 \mathrm{~b}$ & $8.73 \mathrm{~b}$ & $2.06 \mathrm{~b}$ & $0.78 \mathrm{a}$ & $1.05 \mathrm{a}$ \\
\hline LSD & 0.31 & 0.45 & 1.04 & 0.36 & 0.20 & 0.18 \\
\hline \multicolumn{7}{|l|}{ Bunch covering } \\
\hline Control & $4.05 \mathrm{~b}$ & $2.41 \mathrm{a}$ & $8.90 \mathrm{a}$ & $2.62 \mathrm{a}$ & $0.82 \mathrm{a}$ & $0.95 \mathrm{a}$ \\
\hline Bunch covering & $4.72 \mathrm{a}$ & $2.62 \mathrm{a}$ & $9.31 \mathrm{a}$ & $2.41 \mathrm{a}$ & $0.74 \mathrm{a}$ & $1.06 \mathrm{a}$ \\
\hline LSD & 0.25 & 0.37 & 8.85 & 0.29 & 0.16 & 0.14 \\
\hline Thinning $\mathrm{x}$ bunch covering & NS & NS & NS & NS & NS & NS \\
\hline
\end{tabular}

z Means within each column for each treatment followed by the same letter are not significantly different at $P=0.05$.

y $\mathrm{NS}=$ non significant. 


\section{References}

AHMED B.H., MEHANA S.A., ZAGZOG O.A., QAUOD E.M., 2019 - Improvements of yield and fruits quality of zaghlool date palm by using the different thinning treatments. - J. Product. Dev., 4: 743-756.

ALEID S.M., 2014 - Date fruits processing and processed products, pp. 171-202. - In: SIDDIQ M., ALEID S.M., KADER A.A. (eds.) Dates: Postharvest Science, Processing Technology and Health Benefits. WileyBlackwell, USA, pp. 326.

AL-QURASHI A.D., AWAD M.A., 2011 - Quality characteristics of bisir 'Barhee' dates during cold storage as affected by postharvest dipping in gibberellic acid, naphthaleneacetic acid and benzyladenine. - Fruit., 66: 343352.

AL-TURKI S., SHAHBA M.A., STUSHNOFF C., 2010 - Diversity of antioxidant properties and phenolic content of date palm (Phoenix dactylifera L.) fruit as affected by cultivar and location. - J. Food. Agric. Env., 8: 253-260.

AWAD M.A., AL-QURASHI A.D., 2012 - Gibberellic acid spray and bunch bagging increase bunch weight and improve fruits quality of 'Barhee' date palm cultivar under hot arid conditions. - Sci. Hort., 138: 96-100.

AWAD M.A., AL-QURASHI A.D., 2015 - Influences of different whole bunch removal or bunch thinning treatments on yield and fruits quality of three date palm cultivars. Wulfenia, 2: 479-493.

CHEN C.S., ZHANG D., WANG Y.Q., LI P.M., MA F.W., 2012 Effects of fruit bagging on the contents of phenolic compounds in the peel and flesh of 'Golden Delicious', 'Red Delicious', and 'Royal Gala' apples. -Sci. Hort., 142: 68-73.

CHONHENCHOB V., KAMHANGWONG D., KRUENATE J., KHONGRAT K., TANGCHANTRA N., WICHAI U., SINGH S.P., 2011 - Pre-harvest bagging with wavelength-selective materials enhances development and quality of mango (Mangifera indica L.) cv. Nam Dok Mai 4. - J. Sci. Food. Agric., 91: 664-671.

EHTESHAMI S., ABDOLLAHIA F., RAMEZANIAN A., DASTJERDI A.M., RAHIMZADEH M., 2019 - Enhanced chilling tolerance of pomegranate fruit by edible coatings combined with malic and oxalic acid treatments. - Sci. Hortic., 250: 388-398.

EL-BADAWY H.E.M., EL-GIOUSHY S.F., AHMED I.A.M., 2018 - Effect of some thinning practices on yield and fruits quality of Sewi date palm grown in Farafra region. Asian J. Agric. Hort. Res, 3: 1-20.

ETEMADIPOOR R., DASTJERDI A.M., RAMEZANIAN A., EHTESHAMI S., 2020 - Ameliorative effect of gum arabic, oleic acid and/or cinnamon essential oil on chilling injury and quality loss of guava fruits. - Sci. Hort., 266: 1-10.

ETEMADIPOOR R., RAMEZANIAN A., DASTJERDI A.M., SHAMILI M., 2019 - The potential of gum Arabic enriched with cinnamon essential oil for improving the qualitative characteristics and storability of guava (Psidium guajava L.) fruits. - Sci. Hort., 251: 101-107.

FAO, 2018 - FAOSTAT. - FAO, Food and Agriculture Organization of the United Nations. http://www.fao.org/faostat/en/\#data/QC.

GRIÑÁN I., MORALES D., GALINDO A., TORRECILLAS A., PÉREZ-LOPEZ D., MORIANA A., COLLADO-GONZALEZ J., CARBONELL-BARRACHINA A.A., HERNANDEZ F., 2019 Effect of pre-harvest fruits bagging on fruits quality characteristics and incidence of fruits physiopathies in fully irrigated and water stressed pomegranate trees. J. Sci. Food Agric., 3: 1425-1433.

HARHASH M.M., AL-OBEED R.S., 2010 - Effect of bunch bagging color on yield and fruits quality of date palm. American-Eurasian J. Agric. Environ. Sci., 7(3): 312-319.

HARHASH M.M., MOSA W.F.A., EL-NAWAM S.M., GATTAS H.R., 2020 - Effect of bunch covering on yield and fruits quality of 'Barhee' date palm cultivar. - Middle East J., 1: 46-51.

HASAN M.A., BHATTACHARJEE S., DEBNATH U., 2001 Fruits quality and microclimate variation inside the bunch cover of dwarf cavendish banana (Musa AAA). Orissa J. Hort., 29: 46-50.

HUSSAIN I., AHMAD S., AMJAD M., AHMED R., 2016 Execution of strands thinning improves the phytochemicals and sugars profiling in date palm (Phoenix dactylifera L.) fruits. - Pakistan J. Pharmaceutical Sci., 4: 12091215.

KASSEM H.A., EZZ T.M., MARZOUK H.A., 2010 - Effect of bunch bagging on productivity, ripening speed and postharvest fruits quality of 'Zaghloul' dates.- IV International date palm conference, 882, pp. 10911098.

KASSEM H.A., OMAR A.K.H., AHMED M.A., 2011 Response of 'Zaghloul' date palm productivity, ripening and quality to different polyethylene bagging treatments. - American-Eurasian J. Agric. Environ. Sci., 11(5): 616-621.

MARZOUK H.A., KASSEM H.A., 2011 - Improving fruits quality, nutritional value and yield of Zaghloul dates by the application of organic and/or mineral fertilizers. Sci. Hort., 3: 249-254.

MOUSTAFA A.R., ABDEL-HAMID N., EL-HAMID A.A., ELSONBATY M.R., EL-NABY S.A., 2019 - Strand thinning of Khadrawi date palm cultivar in relation to yield and fruits quality. - Bull. Natl. Res. Cen., 1: 204.

RADWAN E.M.A., 2017 - Response of Bent Aisha and Sewy date palm to some fruits thinning treatments. -Assiut J. Agric. Sci., 2: 115-126.

SAMOUNI M., EL-SALHY A.M., BADAWY I.F., AHMED E.F., 2016 - Effect of pollination and thinning methods on yield and fruits quality of Saidy date palms. - Assiut J. Agric. Sci., 47: 92-103.

SERRANO M., PRETEL M.T., BOTELLA M.A., AMOROS A., 2001 - Physicochemical changes during date ripening related to ethylene production. - Food Sci. Technol. Int., 
7: 31-36.

SHARMA R.R., PAL R.K., 2012 - Fruits bagging of apple fruit for better colour and quality. - ICAR News., 4: 3-4.

SHARMA R.R., REDDY S.V.R., JHALEGAR M.J., 2014 - Preharvest fruits bagging: a useful approach for plant protection and improved post-harvest fruits quality-a review. - J. Hort. Sci. Biotech., 2: 101-113.

SHARMA R.R., SANIKOMMU V.R., 2018 - Pre-harvest fruits bagging for better protection and postharvest quality of horticultural produce, pp. 455-489. - In: SIDDIQUI
M.W. (ed.) Pre-harvest modulation of postharvest fruits and vegetable quality. Academic Press, London, UK, pp. 516.

SIDDIQ M., ALEID S.M., KADER A.A., 2013 - Dates: postharvest science, processing technology and health benefits. - John Wiley \& Sons, USA, pp. 326.

SLATNAR A., MIKULIC-PETKOVSEK M., STAMPAR F., VEBERIC R., MARSIC N.K., 2020 - Influence of cluster thinning on quantitative and qualitative parameters of cherry tomato. - Eur. J. Hort. Sci., 1: 30-33. 
